\title{
PENGARUH RASIO LIKUIDITAS, PROFITABILITAS, SOLVABILITAS, AKTIVITAS DAN PENILAIAN PASAR TERHADAP RETURN SAHAM
}

\author{
Putu Eka Dianita Marvilianti Dewi* \\ Universitas Pendidikan Ganesha, Jalan Udayana No.1 1, Singaraja-Bali, \\ Indonesia \\ *(ekadyanita@gmail.com)
}

\begin{abstract}
ABSTRAK
Penelitian ini bertujuan untuk mengetahui pengaruh likuiditas, profitabilitas, solvabilitas, rasio aktivitas dan penilaian pasar terhadap return saham pada perusahaan manufaktur di Bursa Efek Indonesia periode 2011-2015. Sampel yang digunakan dalam penelitian ini yaitu 35 perusahaan yang dipilih dengan menggunakan teknik purposive sampling. Metode analisis yang digunakan adalah regresi linear berganda melalui metode observasi non partisipan. Pengujian secara parsial menunjukkan bahwa variabel likuiditas, profitabilitas, rasio aktivitas dan penilaian pasar berpengaruh positif dan signifikan terhadap return saham, sedangkan variabel solvabilitas berpengaruh negatif signifikan terhadap return saham.
\end{abstract}

Kata kunci: return saham, likuiditas, profitabilitas, solvabilitas, rasio aktivitas, penilaian pasar

\begin{abstract}
This study aimed to determine the effect of liquidity, profitability, solvability, activity ratio and market valuation on the stock return of manufacturing companies in the Indonesian Stock Exchange (Bursa Efek Indonesia) on a period of 2011-2015. The samples are 35 companies choosed by using purposive sampling technique. The analytical method used is multiple linier regressions through non participant observation methods. Results showed that, partially, the variables of liquidity, profitability, activity ratio and market valuation have a positive and significant impact on stock return, while the solvability have a significant negative effect on stock return.
\end{abstract}

Keywords: stock return, liquidity, profitability, solvability, activity ratio, market valuation 


\section{PENDAHULUAN}

Pasar modal telah memberikan alternative investasi bagi para investor. Kini, investasi investor tidak hanya terbatas pada "aktiva riil" dan simpanan pada sistem perbankan, tetapi sudah berkembang ke penanaman dana di pasar modal. Salah satu instrumen yang paling diminati adalah saham. Para investor termotivasi untuk melakukan investasi salah satunya dengan membeli saham perusahaan dengan harapan untuk mendapatkan kembalian investasi yang sesuai dengan yang telah diinvestasikannya. Return merupakan hasil yang diperoleh dari suatu investasi. Return tersebut dapat berupa capital gain ataupun deviden untuk investasi pada saham dan pendapatan bunga untuk investasi pada surat hutang, sehingga merupakan indikator untuk meningkatkan kemakmuran para investor, termasuk didalamnya para pemegang saham. Harga suatu sekuritas akan dipengaruhi oleh kinerja perusahaan, kinerja perusahaan itu sendiri akan dipengaruhi oleh kondisi industri dan perekonomian secara umum. Banyak indikator yang digunakan dalam analisis kinerja perusahaan antara lain, likuiditas, profitabilitas, solvabilitas, aktivitas dan rasio penilaian pasar.

Likuiditas merupakan salah satu faktor yang dapat mendorong terjadi perubahan harga saham. Likuiditas tinggi menunjukkan kemampuan perusahaan dalam memenuhi kewajiban jangka pendeknya. Likuiditas perusahaan dapat diukur dengan rasio lancar. Rasio lancar menunjukkan kemampuan perusahaan untuk membayar utang lancar dengan menggunakan aktiva lancar yang dimiliki (Sudana, 2009:24). Penelitian Krisyanto (2011) menggunakan rasio profitabilitas, leverage, likuiditas, aktivitas dan penilaian pasar dalam mempengaruhi return saham. Penelitian ini menemukan bahwa penilaian pasar berpengaruh positif dan signifikan terhadap return saham dan profitabilitas berpengaruh negatif tidak signifikan terhadap return saham dan leverage memiliki pengaruh yang positif dan signifikan terhadap return saham. Dan rasio aktivitas tidak berpengaruh signifikan terhadap return saham.

Penelitian ini mengambil rasio profitabilitas karena merupakan rasio yang digunakan utnuk mengetahui kemampuan perusahaan dalam menghasilkan laba, salah satu proksi yang digunakan adalah ROA. Proksi 
ini digunakan karena ingin mengetahui pengaruh profitabilitas terhadap return saham melalui total aktiva atau total asset yang dimiliki oleh perusahaan (Wiagustini, 2012:81). Rasio solvabilitas dipilih karena merupakan rasio yang digunakan untuk mengukur kemampuan perusahaan dalam menggunakan hutang, salah satu proksi yang digunakan adalah DER. Rasio ini digunakan untuk menilai hutang dengan ekuitas melalui perbandingan antara hutang lancar dengan seluruh ekuitas (Kasmir, 2013:157)

Sementara itu, rasio likuiditas merupakan rasio yang digunakan untuk mengetahui seberapa besar perusahaan dapat memenuhi jangka pendeknya dengan dana yang tersedia. Proksi yang digunakan yaitu current ratio karena proksi ini menunjukkan kemampuan perusahaan memenuhi kewajiban jangka pendeknya melalui return saham. Di lain pihak, rasio aktivitas merupakan rasio yang digunakan untuk megukur seberapa efisiensi seluruh aktiva perusahaan yang digunakan untuk menunjang kegiatan penjualan. Proksi yang digunakan yaitu TATO. Terakhir, rasio penilaian pasar merupakan rasio yang digunakan untuk mengukur kemampuan perusahaan dalam menciptakan nilai pasar pada masyarakat maupun investor. Proksi yang digunakan adalah PER, proksi ini merupakan ukuran yang paling banyak digunakan oleh investor untuk menentukan apakah investasi modal yang dilakukannya menguntungkan atau merugikan. Salah satu keunggulan menggunakan rasio dapat digunakan untuk membandingkan hubungan return dan resiko dari perusahaan dengan ukuran yang berbeda. Rasio juga dapat menunjukkan profil suatu perusahaan, karakteristik ekonomi, strategi bersaing dan keunikan karakteristik operasi, keuangan dan investasi.

Return merupakan hasil yang diperoleh dari suatu investasi. Menurut Jogiyanto (2013: 235), return saham dibedakan menjadi dua yaitu: return realisasi dan return ekspektasi. Return realisasi merupakan return yang sudah terjadi dan dihitung berdasarkan data historis. Return ini penting dalam mengukur kinerja perusahaan dan sebagai dasar penentuan return dan resiko di masa yang akan datang. Return ekspektasi merupakan return yang diharapkan di masa mendatang dan masih bersifat tidak pasti. Semakin besar return yang diharapkan akan diperoleh dari 
investasi semakin besar pula resikonya.

Berdasarkan latar belakang yang telah diuraikan, permasalahan yang terdapat dalam penelitian ini: "Apakah likuiditas, profitabilitas, solvabilitas, aktivitas dan penilaian pasar berpengaruh signifikan terhadap return saham? Tujuan penelitian ini, untuk mengetahui bagaimana pengaruh likuiditas, profitabilitas, solvabilitas, aktivitas dan penilaian pasar secara parsial terhadap return saham dan mengetahui secara simultan pengaruh likuiditas, profitabilitas, solvabilitas, aktivitas dan penilaian pasar terhadap return saham. Penelitian ini diharapkan dapat memberikan manfaat, baik secara teoritis maupun secara praktis untuk berbagai pihak. Secara teoritis, penelitian ini diharapkan dapat memberikan kontribusi dalam kajian empiris dan menjadi referensi bagi penelitian berikutnya yang sejenis. Secara praktis, penelitian ini diharapkan dapat memberikan tambahan informasi dan masukan dalam memberikan penilaian keputusan yang tepat dalam pengambilan keputusan investasi.

\section{TELAAH LITERATUR DAN PERUMUSAN HIPOTESIS}

\section{Teori Sinyal}

Penelitian ini menggunakan teori sinyal sebagai teori dasar. Menurut Brigham (2011: 186) teori sinyal merupakan suatu tindakan yang diambil oleh manajemen suatu perusahaan memberikan petunjuk kepada investor tentang bagaimana manajemen menilai prospek perusahaan-perusahaan tersebut. Informasi-informasi dalam laporan keuangan merupakan sinyal perusahaan kepada stakeholder yang dapat mempengaruhi pengambilan keputusan. Semakin baik kinerja perusahaan yang tercermin dalam rasio-rasio laporan keuangan, menyebabkan investor semakin tertarik menanamkan sahamnya.

Rasio likuiditas mengukur kemampuan perusahaan meemnuhi kewajiban jangka pendeknya. Penelitian ini menggunakan current rasio sebagai proksinya karena menunjukkan sejauh mana aktiva lancar menutupi kewajibankewajiban lancar. Semakin besar perbandingan aktiva lancar dan kewajiban lancar semakin tinggi kemampuan perusahaan menutupi kewajiban jangka pendeknya. Semakin baik current rasio mencerminkan semakin likuid 
perusahaan tersebut, sehingga kemampuan untuk memenuhi kewajiban jangka pendeknya semakin tinggi, hal ini akan mampu meningkatkan kredibilitas perusahaan di mata investorsehingga akan mampu meningkatkan return saham perusahaan. Hal ini terbukti dari penelitian yang dilakukan oleh shandy (2013) dan Parwati (2016) yang mana current rasio berpengaruh positif terhadap return saham.

Rasio

menunjukkan

profitabilitas

perusahaan memperoleh laba atau ukuran efektifitas pengelolaan manajemen perusahaan. ROA digunakan untuk mengukur efektifitas perusahaan, dengan meningkatnya ROA berarti kinerja perusahaan semakin baik dan sebagai dampaknya harga saham perusahaan semakin meningkat, sehingga return saham perusahaan yang bersangkutan juga akan meningkat. Berarti ROA berpengaruh positif terhadap return saham. Hal ini sesuai dengan penelitian Ulupui (2007), Prihantini (2009), Malintan (2010), susilowati (2011), Parwati (2016) yang membuktikan bahwa ROA berpengaruh yang positif terhadap return saham.

Rasio solvabilitas mengukur kemampuan perusahaan memenuhi kewajiban-kewajiban jangka panjangnya. DER merupakan rasio yang digunakan untuk menilai hutang dengan ekuitas. Rasio ini diukur dengan membandingkan antara hutang termasuk hutang lancar dengan seluruh ekuitas (Kasmir, 2013:157). Jadi DER merupakan perbandingan antara total hutang dan modal yang menunjukkan kemampuan perusahaan untuk memenuhi kewajiban dengan menggunakan modal yang ada. Menurut hasil penelitian Ulupui (2006) menyatakan bahwa DER berpengaruh positif tetapi tidak signifikan. Hal ini bertentangan dengan hasil penelitian Parwati (2016) bahwa DER berpengaruh negatif dan signifikan terhadap return saham.

Rasio aktivitas menunjukkan kemampuan perusahaan dalam memanfaatkan harta yang dimilikinya. Proksi yang digunakan untuk mengukur rasio aktivitas yaitu TATO. Rasio ini menunjukkan tingkat efisiensi penggunaan keseluruhan aktiva perusahaan dalam menghasilkan volume penjualan tertentu (syamsudin, 2009:19). Semakin besar rasio ini semakin baik yang berarti bahwa aktiva dapat lebih cepat berputar dan meraih laba sehingga menunjukkan semakin efisien penggunaan keseluruhan 
aktiva dalam menghasilkan penjualan. Hal ini terbukti dengan penelitian yang dilakukan oleh Subalno (2010) bahwa TATO berpengaruh positif signifikan terhadap return saham berbeda dengan Ulupui (2010) bahwa TATO menunjukkan hasil negatif tetapi tidak signifikan terhadap return saham.

Penilaian pasar menunjukkan pengakuan pasar terhadap kondisi keuangan yang dicapai perusahaan atau mengukur kemampuan manajemen dalam menciptakan nilai pasarnya diatas biaya investasi. Aspek penilaian pasar bisa dilihat dari perbandingan antara harga pasar saham dengan posisi keuangan perusahaan. Semakin tinggi PER maka harga saham dinilai semakin tinggi oleh investor terhadap pendapatan per lembar sahamnya. Dapat disimpulkan bahwa PER yang tinggi akan mengakibatkan return saham naik. Hal ini terbukti dengan penelitian Yulian (2010), Aras (2014) dan Parwati (2016) yang mana PER berpengaruh positi terhadap return saham.

Berdasarkan teori dan penelitian-penelitian sebelumnya, maka dapat ditarik hipotesis sebagai berikut:
$H_{1}$ : Lukuiditas berpengaruh positif signifikan terhadap return saham.

$\mathrm{H}_{2}$ : Profitabilitas berpengaruh positif signifikan terhadap return saham.

$\mathrm{H}_{3}$ : Solvabilitas berpengaruh negatif signifikan terhadap return saham.

$H_{4}$ : Rasio aktivitas berpengaruh positif signifikan terhadap return saham

$H_{5}$ : Penilaian pasar berpengaruh positif signifikan terhadap return saham.

$H_{6}$ : Likuiditas, $\quad$ profitabilitas, solvabilitas, aktivitas, dan penilaian pasar yang diproksikan secara berurutan oleh current rasio, ROA, DER, PER dan TATO secara simultan berpengaruh terhadap return saham.

\section{METODE}

Penelitian ini dilakukan pada perusahaan manufaktur yang terdaftar di BEI tahun 2011-2015. Penelitian ini menggunakan jenis data kuantitatif dan sumber data sekunder, berupa laporan keuangan dari perusahaan manufaktur yang terdaftar di BEI pada tahun 20112015 yang diakses melalui $\underline{w w w . i d x . c o . i d}$ dan data-data dalam Indonesian Capital Market Directory (ICMD). 
Variabel terikat (Y) dalam penelitian ini adalah return saham, konsep return saham dalam penelitian ini adalah harga saham saat ini dikurangi harga saham periode sebelumnya dibandingkan dengan harga saham periode sebelumnya. Menurut Hartono (2010), besarnya return saham dapat dirumuskan sebagai berikut:

$$
R_{i t}=\frac{P_{i t}-P_{i t-1}}{P_{i t}} \times 100 \%
$$

Keterangan :

$R_{i t}=$ return saham periode ke $\mathrm{t}$

$P_{i t}=$ harga saham pada periode ke $\mathrm{t}$

$P_{\text {it }-1}=$ harga saham pada periode $\mathrm{t}-1$

Variabel bebas pada penelitian ini ada lima: Variabel likuiditas (X1), profitabilitas (X2), solvabilitas (X3), Aktivitas (X4) dan penilaian pasar (X5). Variabel likuiditas (X1) diukur dengan current rasio yaitu kemampuan perusahaan memenuhi hutang jangka pendeknya dengan menggunakan aktiva lancar.

\section{Current rasio}

$=\frac{\text { Aktiva lancar }}{\text { Hutang lancar }} \times 100 \%$

Variabel profitabilitas (X2) diukur dengan menggunakan ROA.

ROA

$=\frac{\text { Laba bersih }}{\text { Total Asset }} \times 100 \%$

Variabel solvabilitas (X3) diukur dengan proksi DER.
DER

$=\frac{\text { Total hutang }}{\text { Modal sendiri }} \times 100 \%$

Variabel aktivitas (X4) diukur dengan TATO.

\section{TATO}

$=\frac{\text { Penjualan }}{\text { Total aktiva }} \times 100 \%$

Variabel penilaian pasar diukur dengan PER.

\section{PER}

$=\frac{\text { Harga pasarsaham }}{\text { Laba bersih per saham }} \times 100 \% \ldots . . . . . . . . .(6)$
Populasi penelitian ini menggunakan perusahaan manufaktur yang terdaftar di BEI 2011-2015. Kriteria-kriteria yang ditentukan dalam penelitian ini untuk penentuan sampel: a) perusahaan manufaktur yang terdaftar di BEI selama lima tahun berturut-turut pada tahun 2011-2015, b) tersedia data yang lengkap berkenaan dengan variabel penelitian, c) laporan keuangan harus mempunyai tahun buku yang berakhir per 31 Desember, dan d) perusahaan tidak mengalami kerugian selama periode pengamatan. Berdasarkan proses seleksi sampel diperoleh 35 perusahaan. Total sampel yang diambil selama lima tahun pengamatan adalah sebanyak 175 pengamatan. Proses pemilihan sampel dapat dilihat pada tabel 1 . 
Metode pengumpulan data yang digunakan dalam penelitian ini adalah metode obervasi non partisipan, dimana peneliti dapat melakukan pengamatan tapi tidak terlibat langsung dan hanya sebagai pengamat independen (Sugiyono, 2013:204). Data diperoleh dengan cara melakukan pengamatan dan mencatat serta mempelajari uraian uraian dari buku,jurnal, skripsi, tesis, dan literature lain yang terkait dengan penelitian yang dilakakukan serta mengakses laporan keuangan perusahaan yang terdaftar di BEI melalui situs $\underline{w w w . i d x . c o . i d}$.
Teknik analisis data yang digunakan dalam penelitian ini analisis regresi berganda. Analisis regresi linear berganda dalam penelitian ini digunakan untuk mengetahui pengaruh current rasio, ROA, DER, TATO dan PER etrhadap return saham pada perusahaan manufaktur yang terdaftar di BEI tahun 2011-2015. Untuk dapat melakukan analisis regresi linear berganda diperlukan uji asumsi Pengujian ini dimaksudkan untuk memastikan bahwa model yang diperoleh benar-benar memenuhi asumsi dasar dalam analisis regresi.

Tabel 1. Proses Pemilihan Sampel

Kriteria

Terdaftar di BEI

Perusahaan manufaktur yang tidak sesuai dengan variabel penelitian 75

Perusahaan manufaktur yang tidak konsisten terdaftar pada tahun 201116 2015

Perusahaan manufaktur yang tidak memiliki tahun buku yang berakhir per

31 Desember

Perusahaan yang tidak mengalami kerugian selama periode 2011-2015

Jumlah sampel perusahaan

Jumlah pengamatan penelitian (5 tahun)

\section{HASIL DAN PEMBAHASAN}

Variabel-variabel digunakan dalam penelitian ini adalah variabel return saham (Y) likuidkitas yang diproksikan dengan current rasio (X1), profitabilitas yang diproksikan dengan ROA (X2), 
solvabilitas diproksikan dengan DER (X3), aktivitas diproksikan dengan TATO (X4) dan penilaian pasar diproksikan dengan PER (X5). Analisis data deskriptif dilakukan untuk memberikan gambaran atau deskripsi mengenai variabel yang diteliti seperti pada tabel 2 .

Tabel 2 menunjukkan bahwa jumlah data yang digunakan dalam penelitian 175 sampel data. Variabel current rasio memiliki nilai minimum
0,00 persen, artinya perbandingan laba bersih setelah pajak dengan total asset perusahaan sebesar 0,00 persen. Nilai maksimum current rasio sebesar 0.42 persen artinya laba bersih setelah pajak 0,42 persen dari total aset yang dimiliki oleh perusahaan. Rata-rata perbandingan laba bersih setelah pajak dengan total aset perusahaan sebesar 0,13 persen dan memiliki standar deviasi sebesar 0,10 .

Tabel 2. Statistik Deskriptif

\begin{tabular}{lcllll}
\hline Variabel & $\mathrm{N}$ & Minimum & Maksimum & Mean & Std. Deviation \\
\hline CR & 175 & 0,00 & 0,42 & 0,13 & 0,10 \\
ROA & 175 & 0,03 & 49,60 & 2,34 & 5,47 \\
DER & 175 & 0,51 & 11,74 & 2,56 & 1,88 \\
TATO & 175 & 0,01 & 5,31 & 1,28 & 0,66 \\
PER & 175 & 0,20 & 128,02 & 14,53 & 9,15 \\
Return saham & 175 & $-0,99$ & 8,42 & 0,48 & 1,07 \\
\hline
\end{tabular}

Sumber: data diolah

Variabel ROA memiliki nilai minimum 0,03 persen, artinya perbandingan laba bersih setelah pajak dengan total asset perusahaan sebesar 0,03 peresen diperoleh dari perusahaan Budi Acid Jaya Tbk. Pada tahun 2012. Nilai maksimum 49,60 persen, yang diperoleh dari perusahaan Multi Bintang Indonesia Tbk. Pada tahun 2011 yang menunjukkan bahwa perusahaan akan menghasilkan laba bersih setelah pajak 49,60 persen dari total aset yang dimiliki oleh perusahaan. Rata-rata perbandingan laba bersih setelah pajak dengan total aset perusahaan sebesar 2,34 persen dan memiliki standar deviasi sebesar 5,47.

Variabel DER memiliki nilai minimum 0,51 persen, artinya 
perbandingan antara total hutang dengan modal sendiri sebesar 0,51 persen diperoleh dari perusahaan Lion Metal Work Tbk. Tahun 2014. Nilai maksimum DER sebesar 11,74 persen diperoleh dari perusahaan Multi Bintang Indonesia Tbk. Pada tahun 2014. Rata-rata DER sebesar 2,56 persen dan memiliki standar deviasi sebesar 1,88 .

Variabel TATO memiliki nilai minimum 0,01 persen dan nilai maksimum TATO sebesar 5,31 persen. Hasil tersebut menunjukkan bahwa total Asset Turnovern perusahaan manufaktur yang menjadi sampel penelitian berkisar antara 0,01 sampai 5,31 dengan ratarata 1,2817 pada standar deviasi sebesar 0,66. Nilai rata-rata lebih besar dari standar deviasi yaitu: 1,2817>0,66, berarti bahwa sebaran nilai TOT baik. TOT tertinggi terjadi pada perusahaan Pan Brother Tbk. Yaitu sebesar 5,31, sedangkan TOT terendah terjadi pada perusahaan Alakasa Industrindo Tbk. Sebsar 0,01 .

Variabel PER memiliki nilai minimum 0,20 persen, artinya perbandingan antara harga perlembar saham dengan laba perlembar saham sebesar 0,20 persen diperoleh dari perusahaan Sepatu Bata Tbk. Pada tahun 2014. Nilai maksimum PER sebesar 128,02 kali diperoleh dari perusahaan Budi Acid Jaya Tbk. Pada tahun 2014. Rata-rata PER sebesar 14,53 kali dan memiliki standar deviasi sebesar 9,15.

Variabel return saham memiliki nilai minimum 99 persen, artinya perbandingan harga saham periode sekarang dengan harga saham periode sebelumnya sebesar 99 persen diperoleh dari perusahaan Multi Bintang Indonesia Tbk pada tahun 2014. Nilai maksimum return saham sebesar 8,42 persen yang diperoleh dari perusahaan mayora Indah Tbk, pada tahun 2010 yang menunjukkan bahwa perusahaan menghasilkan harga saham periode sekarang sebesar 8,42 persen. Ratarata perbandingan harga saham periode sekarang dengan harga saham periode sebelumnya sebesar 0,48 persen dan memiliki standar deviasi sebesar 1,07 .

Uji asumsi klasik dilakukan terhadap variabel-variabel yang ada agar tidak terjadi bias dalam pengujian. Uji asumsi klasik meliputi uji normalitas, uji autokorelasi, uji multikolinieritas dan uji heteroskedasitas. Uji normalitas merupakan suatu uji statistk yang bertujuan untuk mengetahui distribusi data variabel yang akan digunakan dala penelitian apakah 
berdistribusi normal atau tidak. Data dikatakan berdistribusi normal jika nilai Asymp, sig (2-tailed)>level of significant $(a)=5 \%$. Hasil pengujian pada variabel Current rasio, ROA, DER dan PER terbuki berdistribusi normal, hak ini ditunjukkan oleh nilai Asymp. Sig (2-tailed) sebesar 0,078 yang lebih besar dari tingkat signifikansi $(0,05)$.

Uji autokorelasi bertujuan untuk mengetahui apakah dalam model regresi linier ada korelasi antara kesalahan pengganggu pada periode $\mathrm{t}$ dengan kesalahan pengganggu pada periode $\mathrm{t}-1$. Uji autokorelasi dalam penelitian ini dilakukan dengan $\mathrm{Uji}$ Durbin Watson. Tabel 3 memperlihatkan nilai Durbin Watson sebesar 1,843 dengan jumlah sampel 175 dan jumlah variabel independen 5, dengan nilai $\mathrm{Du}=1,7567$ dan $\mathrm{dL}=2,2433$. Hal ini berarti nilai Durbin Watson tersebut berada diantara dU dan dL (4-dU) yang menunjukkan tidak adanya gejala autokorelasi.

Tabel 3. Hasil Uji Autokorelasi

\begin{tabular}{ccc}
\hline Batas Bawah & Durbin-Watson & Batas atas \\
\hline$(\mathrm{dU})=1,7567$ & 1,843 & $(4-\mathrm{dU})=2,2433$ \\
\hline
\end{tabular}

Sumber: Data Diolah

Uji Multikolineritas bertujuan untuk menguji apakah model regresi ditemukan adanya korelasi antar variabel bebas. Untuk mendeteksi ada tidaknya korelasi antar sesame variabel bebas dapat dilihat dari nilai tolerance dan nilai variance inflation factor (VIF). Jika nilai tolerance lebih dari 10 persen atau VIF kurang dari 10, maka dikatakan tidak ada multikolinearitas. Dapat dilihat pada table 4, nilai tolerance untuk variabel current rasio, ROA, DER, TATO dan PER secara berturut-turut sebesar 89,4 persen, 7,74 persen, 95,8 perse, 74,5 persen, dan 82,5 persen. Nilai VIF dari variabel CR, ROA, DER,
TATO, dan PER secara berturut-turut sebesar 1,118, 1,292, 1,044, 1,343, dan 1,212. Nilai tersebut menunjukkan penelitian ini tidak mengalami gejala multikolinearits karena telah memenuhi nilai tolerance lebih dari 10 persen atau VIF kurang dari 10, sehingga model regresi ini layak digunakan dalam penelitian.

Uji heteroskedastisitas bertujuan untuk menguji apakah dalam model regresi terjadi ketidaksamaan varians dan residual satu pengamatan yang lain ke pengamatan lainnya. Berdasarkan tabel 5 dapat diketahui bahwa terdapat variabel bebas yang 
Tabel 4. Rangkuman Hasil Uji Multikolinieritas

\begin{tabular}{ccc}
\hline \multirow{2}{*}{ Model } & \multicolumn{2}{c}{ Collinearity Statistic } \\
\cline { 2 - 3 } & Tolerance & VIF \\
CR & 0,894 & 1,118 \\
ROA & 0,774 & 1,292 \\
DER & 0,958 & 1,044 \\
TATO & 0,745 & 1,343 \\
PER & 0,825 & 1,212 \\
\hline
\end{tabular}

Sumber: Data diolah 
berpengaruh signifikan terhadap residual kuadrat, karena nilai signifikansi lebih besar dari 0,05. Dengan demikian model yang dibuat tidak mengandung gejala heteroskedastisitas, sehingga layak digunakan untuk memprediksi.

Hasil dari pengujian regresi linear berganda dengan menggunakan SPSS 17,0 for windows disajikan pada tabel 6. Persamaan regresinya yaitu:

$\mathrm{Y}=-0,530+0,084 \mathrm{X} 1+4,281 \mathrm{X} 2-$

$$
0.028 \times 3+0,646 \times 4+0,022 \times 5
$$

Keterangan:

$\mathrm{Y}=$ return saham

$X 1$ = likuiditas

$X 2=$ profitabilitas

X3 = solvabilitas

$\mathrm{X} 4$ = Aktivitas

$\mathrm{X} 5$ = penilaian pasar

Persamaan regresi linier

berganda tersebut menunjukkan arah masing-masing variabel bebas terhadap variabel terikatnya. Nilai a adalah -0,530 menunjukkan bahwa apabila tidak ada variabel $\mathrm{CR}$, ROA, DER, TATO dan PER maka return (Y) sebesar 0,530 $\beta_{1}$ adalah 0,084, artinya bahwa setiap CR meningkat sebesar 1 persen, maka return saham akan mengalami peningkatan sebesar 0,084 persen dengan asumsi variabel lainnya konstan. $\beta_{2}$ adalah 4,281, artinya setiap ROA meningkat sebesar
1 persen maka return saham akan mengalami peningkatan sebesar 4,281 persen dengan asumsi variabel lainnya konstan. $\beta_{3}$ adalah $-0,028$ artinya bahwa setiap DER meningkat sebesar 1 persen, maka return saham akan mengalami penurunan sebesar 0,028 persen dan sebaliknya jika $P$ menurun sebesar 1 satuan, maka return saham akan mengalami peningkatan dengan asumsi variabel lainnya konstan. $\beta_{4}$ adalah 0,646 artinya bahwa setiap TATO meningkat sebesar 1 persen, maka return saham akan mengalami penurunan sebesar 0,646 persen dan sebaliknya jika TATO menurun sebesar 1 satuan, maka return saham akan mengalami peningkatan 0,646 dengan asumsi variabel lainnya konstan. $\beta_{5}$ adalah 0,022, artinya bahwa setiap PER meningkat sebesar 1 kali, maka return akan mengalami peningkatan sebesar 0,022 persen dengan asumsi variabel lainnya konstan.

Persamaan regresi linier berganda tersebut menunjukkan arah masing-masing variabel bebas terhadap variabel terikatnya. Nilai a adalah -0,530 menunjukkan bahwa apabila tidak ada variabel $\mathrm{CR}$, ROA, DER, TATO dan PER maka return $(\mathrm{Y})$ sebesar $0,530 \beta_{1}$ adalah 0,084 , artinya bahwa setiap CR meningkat sebesar 1 persen, maka return saham akan 
mengalami peningkatan sebesar 0,084 persen dengan asumsi variabel lainnya konstan. $\beta_{2}$ adalah 4,281, artinya setiap ROA meningkat sebesar
1 persen maka return saham akan mengalami peningkatan sebesar 4,281 persen dengan asumsi variabel lainnya konstan.

Tabel 5. Rangkuman Hasil Uji Heteroskedastisitas

\begin{tabular}{cc}
\hline Variabel & Signifikansi \\
\hline CR & 0,105 \\
ROA & 0,054 \\
DER & 0,196 \\
TATO & 0,692 \\
PER & 0,249 \\
\hline
\end{tabular}

Sumber: Data diolah

Tabel 6. Hasil Analisis Regresi Linier Berganda

\begin{tabular}{ccccc}
\hline \multirow{2}{*}{ Model } & \multicolumn{2}{c}{ Unstandardized Coefficient } & \multirow{2}{*}{ T } & Sig \\
\cline { 2 - 3 } & Beta & Std. error & & \\
\hline Konstanta & $-0,530$ & 0,158 & $-3,349$ & 0,001 \\
CR & 0,084 & 0,038 & 2,226 & 0,027 \\
ROA & 4,281 & 0,778 & 5,502 & 0,000 \\
DER & $-0,028$ & 0,013 & $-2,220$ & 0,028 \\
TATO & 0,646 & 0,165 & 3,926 & 0,000 \\
PER & 0,022 & 0,008 & 2,677 & 0,008 \\
Adjusted & & 0,311 & \\
$R^{2}$ & & 20,628 & \\
F Hitung & \multicolumn{5}{c}{0,000} & \\
Sig. F_hitung & & & \\
\hline
\end{tabular}

Sumber: Output SPSS

$\beta_{3}$ adalah $-0,028$ artinya bahwa setiap DER meningkat sebesar 1 persen, maka return saham akan mengalami penurunan sebesar 0,028 persen dan sebaliknya jika $P$ menurun sebesar 1 satuan, maka return saham akan mengalami peningkatan dengan asumsi variabel lainnya konstan. $\beta_{4}$ adalah 0,646 artinya bahwa setiap TATO meningkat sebesar 1 persen, maka return saham akan mengalami penurunan sebesar 
0,646 persen dan sebaliknya jika TATO menurun sebesar 1 satuan, maka return saham akan mengalami peningkatan 0,646 dengan asumsi variabel lainnya konstan. $\beta_{5}$ adalah 0,022, artinya bahwa setiap PER meningkat sebesar 1 kali, maka return akan mengalami peningkatan sebesar 0,022 persen dengan asumsi variabel lainnya konstan.

Berdasarkan tabel 6 didapat $F_{\text {hitung }}$ sebesar 20,628, sedangkan hasil $\mathrm{F}_{\text {tabel }}(\mathrm{k}-1) ;(\mathrm{n}-\mathrm{k}) \quad \mathrm{F}_{\text {tabel }}=(5-1)$; $(175-5)=2,45$, karena $F_{\text {hitung }}$ lebih besar dari $\mathrm{F}_{\text {tabel }}$ maka $\mathrm{H}_{0}$ ditolak dan $\mathrm{H}_{1}$ diterima. Hal ini berarti likuiditas, profitabilitas, solvabiltas, aktivitas dan penilaian pasar secara serempak mempunyai pengaruh signifikan terhadap return saham. Uji t Statistik merupakan pengujian terhadap hipotesis penelitian. Pengujian ini dilakukan untuk mengetahui masing-masing variable bebasnya secara parsial terhadap variabel terikat dengan membandingkan $\mathrm{T}_{\text {hitung }}$ dengan $\mathrm{T}_{\text {tabel }}$ (besar $\mathrm{T}_{\text {tabel }}=1,980$ ).

Berdasarkan

pengujian pengaruh $\mathrm{CR}$ terhadap return saham, diketahui nilai kritisnya adalah $t$ $(\mathrm{a} ; \mathrm{df})=\mathrm{t}(0,05 ; 170)=1,984$ (Uji satu sisi, sisi kiri) dan $\mathrm{T}_{\text {hitung }}$ sebesar2,226. Oleh karena statistik uji jatuh pada daerah penolakan HO ( $\left.\mathrm{T}_{\text {hitung }}>\mathrm{T}_{\text {tabel}}\right)$ maka HO ditolak dan $\mathrm{H} 1$ diterima. Ini berarti, bahwa CR secara parsial berpengaruh positif dan signifikan terhadap return saham. Pengujian pengaruh ROA terhadap return saham, diketahui nilai kritisnya adalah $\mathrm{t}(\mathrm{a} ; \mathrm{df})=\mathrm{t}(0,05 ; 170)=1,984$ (Uji satu sisi, sisi kanan) dan $T_{\text {hitung }}$ adalah 5,502. Oleh karena statistik uji jatuh pada daerah penolakan HO ( $\left.\mathrm{T}_{\text {hitung }}>\mathrm{T}_{\text {tabel }}\right)$ maka $\mathrm{HO}$ ditolak dan $\mathrm{H} 1$ diterima. Ini berarti, bahwa profitabilitas secara parsial berpengaruh positif dan signifikan terhadap return saham. Berdasarkan pengujian pengaruh DER terhadap return saham, diketahui nilai kritisnya adalah $\mathrm{t}(\mathrm{a} ; \mathrm{df})=\mathrm{t}(0,05 ; 170)=$ 1,984 (Uji satu sisi, sisi kiri) dan thitung sebesar $-2,220$. Oleh karena statistik uji jatuh pada daerah penolakan HO ( $\left.\mathrm{T}_{\text {hitung }}<\mathrm{T}_{\text {tabel }}\right)$ maka HO ditolak dan $\mathrm{H} 1$ diterima. Ini berarti, bahwa solvabilitas secara parsial berpengaruh negatif dan signifikan terhadap return saham.

Total Asset

Turnover berpengaruh positif terhadap return saham. Berdasarkan hasil uji regresi linier berganda diperoleh nilai koefisien regresi sebesar 0,646. Hal ini menunjukkan bahwa pengaruh total asset turnover terhadap return saham adalah searah. Variabel total asset turnover mempunyai $\mathrm{T}_{\text {hitung }}$ sebesar 3,926 dengan probabilitas 
sebesar 0,000. Nilai signifikansi lebih kecil dari tingkat signifikansi yang diharapkan $(0,000<0,05)$ menunjukkan bahwa variabel total asset turnover berpengaruh positif dan signifikan terhadap return saham sehingga hipotesis ini diterima. Sedangkan, pengujian pengaruh PER terhadap return saham, diketahui nilai kritisnya adalah $\mathrm{t}(\mathrm{a} ; \mathrm{df})=$ $\mathrm{t}(0,05 ; 170)=1,984$ (Uji satu sisi,sisi kanan) dan $\mathrm{T}_{\text {hitung }}$ sebesar 2,677. Oleh karena statistik uji jatuh pada daerah penolakan HO ( $\left.\mathrm{T}_{\text {hitung }}>\mathrm{T}_{\text {tabel }}\right)$ maka $\mathrm{HO}$ ditolak dan $\mathrm{H} 1$ diterima.Ini berarti, bahwa priceearning ratio secara parsial berpengaruh positif dan signifikan terhadap return saham. Rasio likuiditas diukur menggunakan current ratio. Current ratio menunjukkan besarnya kewajiban lancar yang ditutup dengan aktiva yang diharapkan akan dikonversi menjadi kas dalam jangka pendek. Semakin tinggi current ratio, maka dapat dikatakan bahwa perusahaan mempunyai kemampuan yang lebih besar dalam memenuhi kewajiban-kewajiban keuangan jangka pendeknya. Hal tersebut didukung oleh balance theory yang menyatakan bahwa perusahaan dengan risiko bisnis rendah menggunakan hutang lebuh banyak, dan menggunakan sedikit hutangpada risiko yang tinggi. Hasil penelitian ini menunjukkan bahwa current ratio memiliki pengaruh positif dan signifikan terhadap return saham. Hasil penelitian ini didukung dengan penelitian yang dilakukan oleh Ulupui (2007), Shandy (2013), Pinkan (2013), dan Awan (2014). Hasil penelitian ini mengindikasikan bahwa jika semakin baik current ratio mencerminkan semakin likuid perusahaan tersebut, sehingga kemampuan untuk memenuhi kemampuan jangka pendeknya semakin tinggi, hal ini akan mampu meningkatkan kredibilitas perusahaan di mata investor sehingga akan mampu meningkatkan return saham perusahaan.

Profitabilitas dapat diukur dengan Return on Asset (ROA) untuk mengukur efektifitas perusahaan di dalam menghasilkan keuntungan dengan memanfaatkan aktiva yang dimilikinya. Dengan meningkatnya ROA berarti kinerja perusahaan semakin baik dan akan direspon oleh pasar maupun investor dengan membeli saham, sebagai dampaknya harga saham perusahaan semakin meningkat. Dengan meningkatnya harga saham, maka return saham perusahaan yang bersangkutan juga meningkat, teori tersebut didukung dengan signal theory yang merupakan 
suatu petunjuk untuk investor menilai prospek perusahaan tersebut. Dengan demikian ROA berpengaruh positif dan signifikan terhadap return saham. Hasil penelitian ini didukung juga oleh penelitian yang dilakukan oleh Susilowati (2011) , Prihantini (2009) dan Malintan (2010). Hasil penelitian ini mengindikasikan bahwa ROA merupakan salah satu indikator keuangan yang sering digunakan dalam menilai kinerja perusahaan. Semakin besar ROA, maka kinerja perusahaan tersebut semakin baik, karena tingkat pengembalian (return) semakin besar.

Rasio solvabilitas dapat diukur mengunakan Debt to Equity Ratio (DER). DER dapat memberikan gambaran mengenai struktur modal yang dimiliki oleh perusahaan sehingga dapat dilihat tingkat risiko tak terbayarkan suatu hutang. Semakin besar Debt to Equity Ratio, menunjukkan semakin besar pula beban perusahaan terhadap pihak luar, baik berupa pokok maupun bunga pinjaman. Pernyataan tersebut didukung oleh trade off theory dimana struktur modal yang menyatakan bahwa perusahaan menukar manfaat pajak dari pendanaan hutang dengan masalah yang timbul oleh potensi kebangkrutan. Hasil penelitian menunjukkan bahwa DER memiliki pengaruh negarif dan signifikan terhadap return saham. Hasil penelitian ini didukung dengan penelitian yang dilakukan oleh Soejoto (2001), Barakat (2014) dan Gilang (2012), hasil penelitian ini mengindikasikan bahwa jika beban perusahaan semakin berat maka kinerja perusahaan semakin memburuk dan hal ini berdampak pada penurunan harga saham di pasar modal. Dengan menurunnya harga saham perusahaan di pasar modal, maka return juga menurun.

Hasil analisis statistik untuk variabel total asset turnover (TATO) diketahui bahwa nilai $\mathrm{t}$ hitung bernilai positif sebesar 3,926. Hasil statistik uji $t$ untuk TATO diperoleh nilai signifikansi sebesar 0,000, dimana lebih kecil dari toleransi kesalahan $\mathrm{a}=0,05$, sehingga dapat disimpulkan bahwa TATO berpengaruh positif dan signifikan terhadap return saham, sehingga hipotesis ini diterima. Rasio Aktivitas adalah rasio yang mengukur kemampuan aktiva perusahaan dalam menghasilkan pendapatan. Total Asset Turnover merupakan rasio aktivitas yang digunakan untukmengukur sampai seberapa besar efektivitas perusahaan dalam menggunakan sumber dayanya yang berupa aset. Semakin tinggi rasio 
ini semakin efisien penggunaan aset dan semakin cepat pengembalian dana dalam bentuk kas. TATO sendiri merupakanrasio antara penjualan dengan total aktiva yang mengukur efisiensi penggunaan aktiva secara keseluruhan. Apabila rasio TATO rendah, hal ini mengindikasikan bahwa perusahaan tidak beroperasi pada volume yang memadai bagi kapasitas investasinya. Jadi jika TATO mengalami peningkatan, maka return saham juga mengalami peningkatan, sehingga TATO berpengaruh positif terhadap return saham. Hasil penelitian ini mendukung penelitian terdahulu yang dilakukan oleh Martani (2009) yang hasilnya menunjukkan bahwa total asset turnover memiliki pengaruh positif dan signifikan terhadap return saham.

Rasio penilaian pasar diukur menggunakan Price Earning Ratio. PER digunakan oleh para investor untuk memprediksi kemampuan perusahaan dalam menghasilkan laba dimasa yang akan datang. Semakin tinggi PER maka harga saham dinilai semakin tinggi oleh investor terhadap pendapatan per lembar sahamnya, sehingga PER yang semakin tinggi juga menunjukkan semakin mahal saham tersebut terhadap pendapatannya. Asumsi tersebut didukung dengan signal theory dimana perusahaan dengan prospek yang sangat cerah tidak melakukan pendanaan melalui saham baru, sementara perusahaan dengan prospek yang buruk memang menyukai pendanaan dengan ekuitas luar yang menyebabkan harga saham meningkat. Hasil penelitian menunjukkan bahwa Price Earning Ratio berpengaruh positif dan signifikan terhadap return saham. Hasil penelitian ini didukung dengan penelitian yang dilakukan oleh Yulian (2010), Malintan (2012), dan Aras (2014). Hasil penelitian ini mengindikasikan bahwa jika harga saham semakin tinggi maka selisihharga saham periode sekarang dengan periode sebelumnya semakin besar, sehingga capital gain juga semakin meningkat, maka PER yang tinggi akan mengakibatkan return saham naik.

\section{KESIMPULAN, IMPLIKASI DAN KETERBATASAN PENELITIAN}

Berdasarkan pembahasan yang telah diuraikan pada bagian sebelumnya, maka diperoleh simpulan sebagai berikut. Current Ratio berpengaruh positif dan signifikan terhadap return saham pada perusahaan manufaktur yang terdaftar di BEI periode 2011-2015. 
Semakin tinggi current ratio, maka dapat dikatakan bahwa perusahaan mempunyai kemampuan yang lebih besar dalam memenuhi kewajibankewajiban keuangan jangka pendeknya. Semakin baik current ratio mencerminkan semakin likuid perusahaan tersebut, sehingga kemampuan untuk memenuhi kemampuan jangka pendeknya semakin tinggi, hal ini akan mampu meningkatkan kredibilitas perusahaan di mata investor sehingga akan mampu meningkatkan return saham perusahaan.

Return On Asset berpengaruh positif dan signifikan terhadap return saham pada perusahaan manufaktur yang terdaftar di BEI periode 20112015. Dengan meningkatnya Return On Asset berarti kinerja perusahaan semakin baik dan sebagai dampaknya harga saham perusahaan semakin meningkat. Dengan meningkatnya harga saham, maka return saham perusahaan yang bersangkutan juga meningkat.

Debt to Equity Ratio berpengaruh negatif dan signifikan terhadap return saham pada perusahaan manufaktur yang terdaftar di BEI periode 20112015.Semakin besar Debt to Equity Ratio, menunjukkan semakin besar pula beban perusahaan terhadap pihak luar, baik berupa pokok maupun bunga pinjaman. Jika beban perusahaan semakin berat maka kinerja perusahaan semakin memburuk dan hal ini berdampak pada penurunan harga saham di pasar modal. Dengan menurunnya harga saham perusahaan di pasar modal, maka return juga menurun.

TATO berpengaruh positif dan signifikan terhadap return saham, sehingga hipotesis ini diterima. Total Asset Turnover merupakan rasio aktivitas yang digunakan untuk mengukur sampai seberapa besar efektivitas perusahaan dalam menggunakan sumber dayanya yang berupa aset. Semakin tinggi rasio ini semakin efisien penggunaan aset dan semakin cepat pengembalian dana dalam bentuk kas. TATO sendiri merupakan rasio antara penjualan dengan total aktiva yang mengukur efisiensi penggunaan aktiva secara keseluruhan. Apabila rasio TATO rendah, hal ini mengindikasikan bahwa perusahaan tidak beroperasi pada volume yang memadai bagi kapasitas investasinya. Jadi jika TATO mengalami peningkatan, maka return saham juga mengalami peningkatan, sehingga TATO berpengaruh positif terhadap return saham.

Price Earning Ratio berpengaruh positif dan signifikan terhadap return 
saham pada perusahaan manufaktur yang terdaftar di BEI periode 20112015. Semakin tinggi PER maka harga saham dinilai semakin tinggi oleh investor terhadap pendapatan per lembar sahamnya, sehingga PER yang semakin tinggi juga menunjukkan semakin mahal saham tersebut terhadap pendapatannya. Jika harga saham semakin tinggi maka selisih harga saham periode sekarang dengan periode sebelumnya semakin besar, sehingga capital gain juga semakin meningkat. Hal ini disebabkan karena capital gain dihitung dari selisih antara harga saham periode sekarang dengan harga saham periode sebelumnya. Maka PER yang tinggi akan mengakibatkan return saham meningkat.

Berdasarkan atas simpulan dan hasil analisis pada bagian sebelumnya, dapat dikemukakan beberapa saran sebagai berikut. Bagi investor dan manajemen perusahaan sebaiknya mengoptimalkan current ratio, return on asset, TATO, dan price earning ratio, karena keempat variabel ini memiliki hubungan positif dan signifikan terhadap return saham. Selain itu, terutama bagi para investor dan manajer investasi dalam keputusan pembelian saham di pasar modal tidak hanya mempertimbangkan pendekatan analisis rasio dalam menilai return suatu saham, tetapi mempertimbangkan faktor di luar kabijakan perusahaan seperti kodisi pasar yang terjadi serta faktor-faktor eksternal yang lain karena hal ini secara tidak langsung akan mempengaruhi keuntungan yang diperoleh dalam melakukan investasi. Bagi peneliti lebih lanjut disarankan untuk menggunakan objek yang lebih luas, tidak hanya pada industri manufaktur tetapi juga jenis usaha lainnya terutama yang termasuk perusahaan perbankan, karena perbankan mempunyai spesifikasi tertentu, peneliti juga perlu menambah periode penelitian yang lebih panjang sehingga hasilnya lebih dapat digeneralisasi serta menambahkan satu atau lebih variabel yang lebih mempengaruhi return saham.

\section{REFERENSI}

Adung, Fachrul Reza. 2010. Analisis Faktor-faktor Fundamental yang Mempengaruhi Return Saham Pada Perusahaan Yang Masuk Dalam Indeks LQ 45 Di Bursa Efek Indonesia Periode Tahun 2004-2008. Jurnal Fakultas Ekonomi Universitas Pembangunan Nasional Yogyakarta. 
Arista, Desy, dan Mr Astohar. 2012. Analisis Faktor-Faktor Yang Mempengaruhi Return Saham (Kasus Pada Perusahaan Manufaktur Yang Go Public di BEI Periode Tahun 2005-2009). Jurnal Ilmu Manajemen Dan Akuntansi Terapan, 3 (1), h: 115.

Aristeidis Samitas dan Chrysovalantis Vasilakis. 2006. Liquidity, volume and dividend yields in stock return data: Evidence from London Stock Exchange. Departemen Administrasi Bisnis, Business School, University of Aegean.

Aras, Guler; Yilmaz, Mustafa Kemal. 2014. Price earning ratio, dividend yield, and market to book ratio to predict return on stock market: Evidence from the emerging markets.

Agus Sartono. 2010. Manajemen Keuangan Teori dan Aplikasi (4th ed.). Yogyakarta: BPFE.

Brigham, E.F., Gapenski, Louis. 1997. Intermediate Financial Management. Fifth Edition.Sea Harbor. Driver: The Dryclen Press.

Brigham, Eugene dan Joel F Houston. 2009. Dasar-Dasar Manajemen Keuangan. Jakarta : Selemba Empat.

Barbe. et al. 1996. Do Sales Price and Debt Quity Ratio (DER) Stock Return Better than Book Market and Firm Size. Journal Financial Analysis, 52(2), pp: 56-63.

Bungin, Burhan. 2010. Metodologi Penelitian Kuantitatif. Edisi Kedua. Kencana.
Dwi Martani, Mulyono, Rahfiani Khairurizka. 2009. The effect of financial ratio, firm size, and cash flow from operating activities in the interim report to the stock return. Jurnal Ekonomi Akuntansi Universitas Indonesia.

Dr. Abdallah Barakat. 2014. The Impact of Financial Structure, Financial Leverage and Profitability on Industrial Companies Shares Value (Applied Study on a Sample of Saudi Industrial Companies). Research Journal of Finance and Accounting . 5 (1), PP : 5566.

Eduardus Tandelilin. 2001. Analisis Investasi dan Manajemen Portofolio Edisi Pertama. Yogyakarta: BPFE Yogyakarta.

Fahmi, Irham. 2012. Manajemen Investasi. Jakarta Selatan: Salemba Empat.

Gilang Pradika. 2012. The Influence of Fonancial ratio Towards Stock Price, 2012 - Empirical Study on Listed Companies in Indonesia Stock Exchange of LQ45 in 2009-2011. Journal Internasional Undergraduate Program in Accounting Faculty of Economic and Business Brawijaya University.

Ghozali, Imam. 2006. Aplikasi Analisis Multivariate Dengan Program SPSS. Semarang: Badan Penerbit Universitas Dipenogoro.

Harahap, Sofyan Syafri. 2009. Analisis Kritis Atas Laporan Keuangan. Jakarta : PT Raja Grafindo Persada. 
Haghiri, Amir dan Soleyman Haghiri. 2012. The Investigation of Effective Factors on Stock Return with Emphasis on ROA and ROE Ratios in Tehran stock exchange (TSE). Journal of Basic and Applied Scientific Research, 2 (9), pp: 9097-9103.

Husnan, Saud dan Enny Pudjiastuti. 2004. Dasar-dasar Manajemen Keuangan. Edisi Kelima. Yogyakarta: UPP STIM YKPN.

Hermuningsih Sri. 2012. Pengantar Pasar Modal. Yogyakarta: UPP STIM YKPN.

Indonesia Stock Exchange. Manufaktur .2011-2015.

Jogiyanto. 2013. Teori Portofolio dan Analisis Investasi. Edisi Kedelapan. Yogyakarta: BPFE.

Kasmir. 2010. Analisis Laporan Keuangan. Jakarta: PT RajaGrafindo Persada.

Krisyanto, R.A. 2011. Pengaruh Rasio Profitabilitas, Laverage, Likuiditas, Aktivitas dan Penilaian Pasar Terhadap Return Saham Pada Perusahaan Manufaktur yang Terdaftar di Bursa Efek Indonesia Tahun 2005-2009. Skripsi. Akuntansi Manajerial Politeknik Negeri Bali.

Maria, Rasheed Awan. 2014. Impact of liquidity, Leverage, inflation on firm profitability an empirical analysis of food sector of Pakistan. Journal of Business and Management (IOSR-JBM)

M. Hanafi, Mamduh dan Abdul Halim. 2009. Analisis Laporan Keuangan. Edisi Keempat. Yogyakarta: UPP STIM YKPN.
Martono, SU dan Harjito, Agus Drs. D., M.Si. 2009. Manajemen Keuanagan. Ekonisi. FE UII. Yogyakarta.

Malinta, Rio and Tubandrijah Herawati. 2013. Pengaruh Current Ratio (CR), Debt to Equity Ratio (DER), Price Earning Ratio (PER), dan Return On Asset (ROA) Terhadap Return Saham Perusahaan Pertambangan yang Terdaftar di Bursa Efek Indonesia Tahun 2005-2010. Jurnal Ilmiah Fakultas Ekonomi dan Bisnis Universitas Brawijaya, 1(1).h:1-25.

Munawir. 2007. Analisis Laporan Keuangan Edisi ke empat. Yogyakarta: Liberty.

Mahmud, m. Hanafi dan Abdul, Halim. 2003. Analisis Laporan Keuangan Edisi Revisi. Yogyakarta: AMP YKPN.

Mulia, Wijaya dan Pande Putu. 2010. Pengaruh Rasio Profitabilitas, Leverage, Likuiditas, Aktivitas, dan ukuran perusahaan Terhadap Return Saham Pada Perusahaan Manufaktur Yang Terdaftar Di Bursa Efek Indonesia Tahun 2004-2008. Skripsi. Fakultas Ekonomi Universitas Udayana Denpasar.

Nata, Wirawan. 2012. Cara Mudah Memahami Statistik 1 (Statistik Deskriptif) untuk Ekonomi dan Bisnis. Denpasar: Keraras Emas.

Nathaniel, Nicky. 2008. Analisis Faktor-Faktor yang Mempengaruhi Return Saham (Studi Pada Saham-Saham Real Estate and Property di Bursa Efek Indonesia Periode 20042006. Tesis. Program Magister 
Manajemen Universitas

Diponegoro. Semarang.

Parwati, Dika Ayu. 2016. Pengaruh Pofitabilitas, Ieverage, Likuiditas dan Penilaian Saham pada PerusahaanManufaktur. $\quad E$ Jurnal Manajemen Unud, Vol. 5, No.1, 2016: 385 - 413 ISSN: 2302-8912

Pinkan, Komala. November 2013. The Effects Of Profitability Ratio, Liquidity, and Debt towards Investment Return. Academic Star Publishing Company Volume 4, no. 11, ISSN 21557950.

Prastowo, Dwi dan Rifka Juliaty. 2002. Analisis Laporan Keuangan. Edisi Revisi. Yogyakarta : UPP AMP YKPN.

Prince Acheampong, Evans Agalega \& Albert Kwabena Shibu. 2014. The Effect of Financial Leverage and Market Size on Stock Returns on the Ghana Stock Exchange: Evidence from Selected Stocks in the Manufacturing Sector Department of Accountancy. Journal Koforidua Polytechnic, P.O.Box KF981, Koforidua, Ghana.

Prihantini, Ratna. 2009. Analisis Pengaruh Inflasi, Nilai Tukar, ROA, DER dan CR Terhadap Return Saham (Studi Kasus Saham Industri Real Estate and Property yang Terdaftar di Bursa Efek Indonesia Periode 2003-2006). Tesis. Universitas Diponegoro. Semarang.

Riyanto, Bambang. 2008. DasarDasar Pembelajaran Perusahaan. BPFE Yogyakarta.
Ross, A Stephen. Westerfield, Randolph W. dan Jordan, Bradford. 2003. Fundamentals Of Corporate Finance Sixth Wdition. Journal. New York: MC Graw-Hill.

Sawir, Agnes.2009. Analisis Kinerja Keuangan dan Perencanaan Keuangan Perusahan. PT. Gramedia Pustaka Utama, Jakarta.

Shandy, Ahmad dan Asyik, Nur Fadjrih. 2013. Pengaruh Profitabilitas dan Likuiditas Terhadap Kebijakan Deviden Kas Pada Perusahaan Otomotif. Jurnal Ilmu dan Riset Akuntansi, 1 (1) , h: 58-76.

Silviana, and Rocky. June 2013. Analiysis of Return On Assets and Earnings Per share on The Stock Market In The Banking Companies In Bursa Efek Indonesia (Indonesia Securities Exchange). INTERNASIONAL CONFERENCE ON MANAGEMENT, ISBN: 978967-5705-11-3.

Sugiyono. 2013. Metode Penelitian Bisnis (Pendekatan Kuantitatif, Kualitatif, dan R\&D). Bandung: Alfabeta.

Sunariyah. 2006. Pengantar Pengetahuan Pasar Modal. Edisi Kelima. Yogyakarta: UPP AMPYKPN.

Susilowati, Yeye. 2011. Reaksi Signal Rasio Profotabilitas dan Ratio Solvabilitas Terhadap Return Saham. Jurnal Dinamika Keuangan dan Perbankan, Vol.3, No.1, pp 17-37.

Stella. 2009. Pengaruh Price to Earning Ratio, Debt to Equity Ratio, Return On Asset, dan Price To Book Value Terhadap 
Harga Pasar Saham. Jurnal Bisnis dan Akuntansi, 11(2), pp:97-106.

Soejoto. 2001. Pengaruh Rasio Profitabilitas dan Laverage Terhadap Return Saham Perusahaan Manufaktur di Bursa Efek Indonesia. Jurnal UNNES: Semarang.

Tuasikal, A. 2001. Penggunaan Informasi Akuntansi untuk Memprediksi Return Saham: Studi terhadap Perusahaan Pemanufakturan dan Nonpemanufakturan.

Simposium Nasional Akuntansi IV. Bandung Agustus; 762786.

Tika, Maya Pribawanti. 2007. Analisis Pengaruh Rasio Keuangan Terhadap Total Return Saham Pada Perusahaan Industri Manufaktur Yang Membagikan Deviden Di Bursa Efek Jakarta. Jurnal Universitas Negeri Semarang

Ulupui, I G K A. 2007. Analisis Pengaruh Rasio Likuiditas, Leverage, Aktivitas, dan Profotabilitas terhadap Return Saham (Studi pada Perusahaan Makanan dan Minuman dengan Katagori Industri Barang dan Konsumsi . Jurnal Akuntansi dan Bisnis, 2(1): h:88-102.

Wahid, Wachyu Adi Winarto. 2007. Pengaruh Kinerja Keuangan Terhadapn Return Saham Perusahaan Manufaktur Yang Terdaftar Di Bursa Efek Jakarta. Skripsi. UNNES. Semarang.

Wiagustini, Ni Luh Putu. 2010. Dasar-Dasar Manajemen Keuangan. Denpasar: Udayana University Press.
Yongyoot, Chairatanawan. 2008. Predictive Power of Financial Ratios to Stock Return in Thailand. Institute of International Studides, Ramkhamhaeng University Bangkok, Thailand 